\title{
The Impact of Decentralization Policy on the Performance of Colleges of Education in Zambia: The Case of Kitwe, Mufulira and Copperbelt College of Education
}

\author{
D. Kambilombilo ${ }^{1} \&$ M. K. Banda ${ }^{2}$ \\ ${ }^{1}$ Mufulira College of Education, P.O Box 40400, Mufulira, Zambia, Central Africa. \\ ${ }^{2}$ School of Graduate Studies, Copperbelt University, P.o Box 21692, Kitwe, Zambia, Central, Africa. \\ Correspondence: Dennis Kambilombilo, Mufulira College of Education, P.O Box 40400, Mufulira, Zambia, Central, \\ Africa.
}

Received: June 12, 2015

doi:10.11114/ijsss.v3i5.973
Accepted: June 25, $2015 \quad$ Available online: July 27, 2015

URL: http://dx.doi.org/10.11114/ijsss.v3i5.973

\begin{abstract}
The purpose of this study was to investigate the impact of decentralization on the performance of public Colleges of Education after the introduction of decentralization policy. The study was conducted on three colleges of education, namely; Kitwe College of Education (KICE), Mufulira College of Education (MUCE) and Copperbelt College of Education (CBCE), now Mukuba University. The three selected institutions are all public teacher training institutions located on the Copperbelt Province of Zambia. The sample consisted of thirty (30) respondents, comprising academic staff and administrators. Ten (10) participants were drawn from each college.

In order to evaluate the impact of decentralization on the performance of public colleges of Education, the researcher decided to use some performance variables (indicators) of decentralization; quality assurance, efficiency and effectiveness, service delivery, transparency and accountability, responsiveness and staff motivation to guide the study in the investigation of the topic at hand.

The methods used to collect data for this study were questionnaires, unstructured interviews and desk research. The research design used for this study was a mixed survey method. Data obtained were analyzed using simple statistics, and the Pearson's correlation model.

The findings of the study were that colleges of educations had failed to take advantage of the decentralization policy as they have continued to depend for instructions and other important things from government. The performance variables showed that nothing significant has taken place in the three sampled public Colleges of Education. Despite this general picture however, the results from individual institution showed significant contrasts among the three institutions sampled on each of the performance indicators.
\end{abstract}

Keywords: Impact, decentralization policy, performance, public colleges of education

\section{Introduction}

\subsection{Introduction to the Problem}

Educational policies depend to a larger extent on the political ideology of the government in power. This is because education is the channel through which government communicates its vision to its citizens. However, these policies are not always determined by individual countries but rather they are a reflection of the external environment or pressures. The 1980s experienced two major revolutions: The political Revolution and the Educational Revolution. During this period there emerged in Europe, Africa, Latin America and Asia political revolutions demanding an end to dictatorship and socialism to be replaced by democracy and free market economy. The disintegration of the Soviet Union in 1991, confirmed the demise of socialism and the triumph of democracy. Therefore, the emergence of democracy gave rise to the demand for more freedoms, human rights, transparency, accountability and privatization. Some authors contended that, this shift occurred partly in response to political pressures for local autonomy, but also to deliver public services more efficiently. The second revolution which took place during this period was in educational thought. Educationalists and Academicians throughout the world started demanding for increased 
participation, access, quality, and efficiency in education.

Thus, as a result of these pressures, many developing nations introduced new policies for governance of public education, in pursuit of national goals of economic growth, democratization and equity.

1.1.1 Reasons for Decentralization of the Education System in Zambia

Before the re-introduction of Multi-Party politics in 1991, the philosophy that guided the education system in Zambia was centred on Humanism. For instance, the education provided during this era did not encourage democratic principles but promoted the values of the ruling party and its guiding philosophy. There was either little or very limited private participation of private sector organizations in the provision of education in Zambia; only the Church or missionaries participated actively in the provision of education. Otherwise, government provided, financed and controlled and maintained the education standards through the Ministry of Education. A policy document entitled, "Principles of Education Boards Government and Management" (August: 2005: 4) summarized the major elements that guided education policy at that time as:

- Equality of educational opportunities for all

- Fostering a sense of nationhood and promoting national unity without necessarily promoting educational uniformity

- Serving the needs of national development without frustrating the full development of individual abilities and satisfactions.

This eventually brought about a highly centralized education management system. Nevertheless, with the dwindling economy in the 1970s through to the 1980s, Government found it difficult to mobilize and let alone finance the expanded education sector satisfactorily due to other competing demands. It followed therefore that, the standards in education could not be maintained due to meager resources. Consequently, there was a general slump in the quality of education. This was further compounded by the inefficient and corrupt bureaucratic system of the civil service.

On the other hand, the wind of change that swept through Europe, Asia, Africa and America impacted strongly on the political, social and economic land scape of Zambia. First there was change of Government in 1991 from United National Independence Party (UNIP) to the Movement for Multi-Party Democracy (MMD) and Dr. Chiluba became the second president of Zambia. This meant a paradigm shift from socialism to democracy and a Free Market Economy system. As such, it became imperative to repeal the old and conservative socialist policies that guided the education system and replace them with policies that would champion the new political dispensation. To this effect four major educational policies were launched between 1991 and 2002. These include: Focus on Learning which was launched in 1992, the National Educational Policy on education, 'Educating Our Future', launched in 1996 and the 'National Decentralization Policy', launched in 2002. 'Focus on Learning' emphasized issues of resource mobilization to support education provision whereas 'Educating Our Future' addressed issues related to democratization, decentralization and productivity on one hand and curriculum relevance and diversification, efficient and costeffective management, capacity building, cost sharing, revitalized partnerships, equity and quality of education on the other hand (Educating Our Future, 1996; Principles of Boards, 2002). Like in the other countries that had already implemented the decentralization policy, education decentralization policy in Zambia was meant to:

- Grant legal and financial powers over education to local units.

- Entrust local units with administrative responsibility and discretion to plan and implement programmes and projects or to adjust central directives to local conditions, within guidelines set by ministry headquarters

- Transfer managerial responsibility for specifically defined education functions to organizations that are outside the regular bureaucratic structure of the education system and that are only indirectly controlled by the Ministry of Education

- Make Government divesting itself of some responsibility for ownership, power and control over education and the transfer of these to voluntary organizations or private enterprises. (Educating Our Future, 1996; Principles of Education Boards, 2002)

\subsubsection{The Research Problem}

The Government of the Republic of Zambia launched the Decentralization Policy in the Ministry of Education in 2002 with the view to improving performance in public education institutions in terms of equity, access, and increased community participation, improved service delivery and quality. To achieve this, the Ministry of Education devolved some powers to management at local units: colleges, high and basic schools to make decisions in areas such as local resource mobilization, student recruitment, and procurement. Makwaya (2005) argued that in practice, decentralization at college level implied establishing board committees to exercise authority and carry out 
responsibilities within the board's jurisdiction.

Now it is over a decade since the decentralization policy was launched in the Ministry of Education and no study has ever been conducted to investigate the performance of Public Colleges of Education in order ascertain whether the benefits of decentralization policy are being realized.

Therefore, this study, being the first to be conducted, when successfully completed, will first and foremost add to the body of knowledge on decentralization in public Colleges of Education in Zambia..

\subsubsection{Scope of the Study}

The study was conducted on the Copperbelt province of Zambia. It was conducted at three public Colleges of Education. These include CBCE, KICE and MUCE. CBCE trains secondary school teachers; KICE trains primary school teachers while MUCE trains junior secondary school teachers. CBCE and KICE are located in Kitwe town while MUCE is situated in Mufulira town of the Copperbelt province. The study was carried out on thirty members of staff; ten in each college.

\subsubsection{Importance of the Problem}

This study is the first of its kind and when successfully completed will first and foremost add to the body of knowledge on decentralization in public Colleges of Education in Zambia. In particular, this study will enable stake holders to understand and appreciate the challenges of decentralization in the Ministry of Education especially in Colleges of Education. Consequently, the study will assist policy makers to develop new ways of implementing and enhancing decentralization policy in the education sector, and particularly in colleges of education in Zambia

\subsubsection{Organization of the rest of the document}

This study is divided into six chapters. Chapter one discusses general background to the study, hence illuminating on research problem, research questions, objectives, limitations and justification of the study including literature review. It includes literature from Latin America, Europe, Asia and Africa. Most, if not all the literature consulted is from developing countries. Chapter two is about the Conceptual and Theoretical frame work. It highlights on the research design, research choice, data collection methods, sampling techniques and data analysis. Chapter three is about research method, while chapter four is research findings whereas chapter five is about discussion of research findings. Chapter six is about conclusions and recommendations.

\subsection{Relevant Scholarship}

\subsubsection{Introduction}

The aim of this section of the chapter was to review the literature concerning Educational Decentralization in public colleges of education. In order to have a clear understanding of Educational Decentralization, the researcher decided to sample some important studies around the world. In this regard, various definitions of decentralization were examined. This enabled the researcher to appreciate the process of decentralization, particularly, decentralization in the Education sector in Zambia. Besides this, the researcher also conducted an exploration on various theories of decentralization and how it has worked in countries where it has been implemented. This assisted the researcher to develop a conceptual/theoretical framework for this study.

\subsubsection{Some definitions of Decentralization}

There are four main types of decentralization, namely; Deconcentration, Delegation, Devolution and Privatization. Deconcentration is the transfer of responsibilities to lower levels, with limited decision- making powers, within ministries or organs of the central government. Delegation on the other hand is the administrative or legal transfer of responsibilities to elected or appointed school governing bodies such as school councils, and school management committees whereas devolution refers to the permanent transfer of decision - making responsibilities in education from the central government to lower levels of government such as provinces, and districts (Weidman J. C and DelpietroJurand R; Di Gropello, 1999). Therefore, from the foregoing definition, it can be noted that we cannot easily tell what type of decentralization a country is pursuing unless we understand the implementation process. To this effect, Karstanje (1991) viewed decentralization as an attempt to maximize effectiveness and efficiency by shortening the distance between the parts of an organization and shifting the risks to a lower level. In a similar manner, (Cheema, Nellis and Rondinelli, 1983; and Anon, 2003) defined decentralization as:

"The transfer of responsibilities for planning, management and resource acquisition and provision from the central government and its organs to field units of central government ministries or bodies, subordinate units or levels of government, semi-autonomous public authorities, non- governmental, private or community based organizations."

Thus, from the sampled definitions, we observe that decentralization contain elements of each or all the four forms of 
decentralization mentioned above.

Having looked at the general definition of decentralization, it's necessary that we narrow down our discussion to Educational Decentralization, the topic of our study. Like decentralization above, Educational Decentralization has been described or defined in different ways by different scholars. Naidoo (2003) for instance, defined Educational Decentralization as a means to establish institutional legitimacy by redistributing power and giving local communities a greater management role and voice.

Therefore, we note that the main idea behind educational decentralization is to entrust local units with some powers to take responsibility in the running of education. Admittedly, it's incumbent upon, each government to choose a form of decentralization which will be suitable and yield the desired and beneficial results for its nationals. This is the reason why the impact of decentralization is felt differently by each country implementing it. This is because governments decide how decentralization should be implemented, who should implement it and when it should be implemented. However, regardless the manner in which decentralization is implemented; proponents of educational decentralization have argued strongly about its benefits.

\subsection{Benefits of Decentralization}

The benefits of Educational Decentralization are many. Apart from reducing the gap between the central government and local units, the proponents of Educational Decentralization argue that, if well implemented, educational decentralization will result into efficiency and effectiveness in the provision of educational services, reduced bureaucratic tendencies thereby leading to the flourishing of transparency and accountability. Asghar (2005), a supporter of Educational Decentralization argued that, the process of decentralization in education will considerably improve transparency, administrative efficiency, parental participation, financial management, the quality and accessibility of services and the development of political responsibility in general. Thus, these and many other benefits will accrue to the education system if the decentralization reforms are well handled. In this respect therefore, it's the responsibility of the government implementing Educational Decentralization reforms to decide how to achieve these benefits by implementing one of the four types of decentralization policies or a combination of them.

\subsection{Theories underlying Educational Decentralization}

The theory underlying Educational Decentralization is that of improved performance of public institutions by granting local organs of the Ministry of Education powers to run education institutions with less or no interference from the central government.

Ironically, the rationale behind decentralizing education is based on breaking the information barrier caused by political, geographical, and cultural distance between centralized governments and communities. Ornelas, Galiani and Schardgrodsky (2002), contended that local governments are better prepared than a distant central government to respond to local education issues, such as curriculum development, teacher training, and school management. Moreover, teachers and school administrators may be more responsive to problems if they are accountable to parents within the community, which may reduce immediate conflicts.

In a nutshell, the proponents of educational decentralization assume that, shifting authority and management responsibilities to local levels will enhance the quality of education, improve effectiveness and efficient use of resources, and increase responsiveness of public education to local needs, teacher and school level professional autonomy. Dyer (2005), observed that, successful implementation depends on strengthening the capacity of local units and the capacity of central governments to facilitate and support decentralization.

\subsection{Experiences on Educational Decentralization}

\subsubsection{Experiences from South America (Latin America)}

One of the studies consulted was Emanuel di Gropello (1999) entitled Education Decentralization and Accountability Relationships in Latin America.

In his study, Di Gropello looked at a broader view of education decentralization in Latin America. Di Gropello stated that decentralization in Latin took three forms, namely; Sub-national government model, Sub-national shared responsibility model and School Autonomization model. Di Gropello argued that, in Sub-national government model emphasis was placed on an immediate political actor at the centre of the decentralization process. Some countries that utilized this model included Argentina and Brazil. On the other hand, the Sub- National shared model encouraged municipalization process of service delivery complimented by regions or departments. This model was prevalent in Colombia and Bolivia. Finally, the School Autonomization model emerged from the idea of school management model and emphasized school autonomy and more community participation in the education provision and delivery. This model was pursued in Nicaragua and El Salvador in Central America. Merchelli (2001) acknowledges that, "There are 
many mechanisms to decentralize and privatize education and they may have different impacts on equity, quality and efficiency. Indeed, their mixed effects may depend on the way policies have been designed and implemented in a specific socio-economic and cultural context." In this regard, we find that in Mexico, Argentina and Colombia, the Ministries of Education retained centralized authority over national policy, curriculum frameworks, academic evaluation, and specialized training. Abisamra (2003) also observed that, educational decentralization in Mexico was motivated by two factors: strengthening policy control at the national level and federalism in education in order to improve the quality and equity of education. Apart from that, Abisamra concluded that the Mexican educational decentralization was more of cooperation and coordination between the states and the federal government

In general however, despite numerous efforts at decentralizing the education system in Latin America, not much headway has been recorded due to various factors ranging from, economic, social, political and geographical. Di Gropello (2003) described the decentralization of education in the countries as limited in the level of participation of the final user and, therefore, had a small impact on achievement.

\subsubsection{Experiences from Asia}

Asia provided an interesting study area as most countries were communist states where the collective takes precedence over the individual. In these countries, governments took a centralized approach with central governments developing, designing, and executing policies for school finance, curriculum, assessment, and teacher preparation.

For instance, a study on decentralization policy of the education system in Pakistan revealed that, decentralization in Pakistan had taken the form of devolution. Naidoo (2000) observed that, the Ministry of Education, in Pakistan undertook educational devolution reforms to address access, equity, and quality. In this way, the Pakistan decentralization of the education system followed the Sub-national government model in that, the government played a significant part in the education sector while at the same time, recognizing the important role of the private sector or other stake holders. In the same vein, China also adopted devolution in its implementation of educational decentralization in the education sector. For instance, the Chinese government issued a document in 1985 which specifically decreed that, "the power for administration of elementary education belongs to local authorities (State Education Commission, 1985).

\subsubsection{Experiences from some African countries}

In order to have an insight of educational decentralization in Africa, the researcher looked at the decentralization drive in Egypt and South Africa. A study by Nasser-Ghodsi (2006) on educational decentralization in Egypt observed that, the main objectives of the Egyptian decentralization effort were centred on: increased access for female education, improved education quality, and open public participation to education issues. In order to realize these objectives, the Ministry of Education passed a decree in 1997announcing the establishment of Parent-Teacher Councils to facilitate the collaboration of school administrators and parents. Coster (2005) contended that, parent-Teacher Councils officially had the responsibility to work with school administrators to address local concerns, improve communication between parents and teachers, and evaluate schools on their cleanliness, equipment, and teaching quality. In addition, the Government through the Ministry of Education passed a Ministerial Decree concerning the establishment of Boards of Trustees, Parents, and Teachers (BoTTPT) across the country, as an effort to nationally decentralize education system.

In case of the South African education decentralization drive, the researcher noted that educational decentralization began seriously after independence in 1994. A study of Educational Decentralization in South Africa revealed that, in the eight years since 1994, there had been a profound restructuring of the South African education system, including a significant element of decentralization. (Naidoo: 2003). Therefore, the restructuring process that the South African Government undertook since 1994, while keeping considerable powers with the national government, had decentralized significant powers to the provincial governments within the context of South Africa's model of co -operative governance. Through the decentralization efforts of the education system, funding to both government and private schools both within and across provinces improved significantly. The South African educational decentralization reforms took the form of devolution.

\subsubsection{Experience from Zambia}

Like other African countries as seen already, Zambia's Educational Decentralization drive was propelled by economic, social and political factors. For example, in the 1980s there was a sharp decline in the Zambian economy which culminated in political discontent with the then UNIP government. The people of Zambia started demanding for a change in the political dispensation of the country: The change from One Party dictatorship system to multi-party politics. This demand was fueled up by the deterioration in social services such as schools, water, housing and health services. Worse still, the decline in the education standards and the subsequent ineffective and corrupt civil service led to the introduction of decentralization policy in education. 
From the outset, the design of educational decentralization in Zambia was such that, it was meant to devolve some of powers or duties of the ministry headquarters to local units such as provincial education offices, district education offices and schools. Although provincial and district offices had some powers, these were insignificant and most often were over shadowed by the bureaucratic nature of the Ministry of Education. Thus, to enhance the development of a new decentralization policy, the Ministry of Education invariably demanded the realignment of the existing management structure with the decentralization of operations in mind, to create a close fit between structure, strategy and policy. With this vision therefore, the path of educational decentralization in Zambia was set devolving power, authority and the relevant functions from national and provincial headquarters to the districts, colleges and schools. Nonetheless, within the decentralized system, the Ministry headquarters retained responsibility for key national functions such as: Making legislation, policy formation, planning, resource mobilization and allocation, developing a national curriculum, setting standards and evaluation, collecting and analyzing data and providing effective mechanisms for accountability at different levels (National Report on Zambia, 2000).

\subsection{Hypotheses}

- $H_{O}$ : Educational decentralization of public Colleges of Education has not resulted into improved performance of these institutions.

- $H_{a}$ : Education decentralization of public Colleges of Education has resulted into improved performance of these institutions

Figure 1.1 is an illustration of how decentralization process gives way or results into improved performance. The figure demonstrates that improved performance of public colleges is dependent on the eight performance variables which in turn depend on each other. Therefore, a faulty in one of these variables, will affect one or more of these variables and therefore the general performance. Thus, as we discuss the performance of the sampled colleges of education, we expect this kind of relations.

\subsection{Operationalization of the hypothesis}

In order to test the hypothesis above, the following variables (indicators) will be used to measure the performance of sampled colleges of education.

- Service Delivery

- Quality Assurance

- Transparency \& Accountability

- Responsiveness

- Efficiency \& Effectiveness

- Communication

- Continuous professional Development

- Staff Motivation

- Staff recruitment

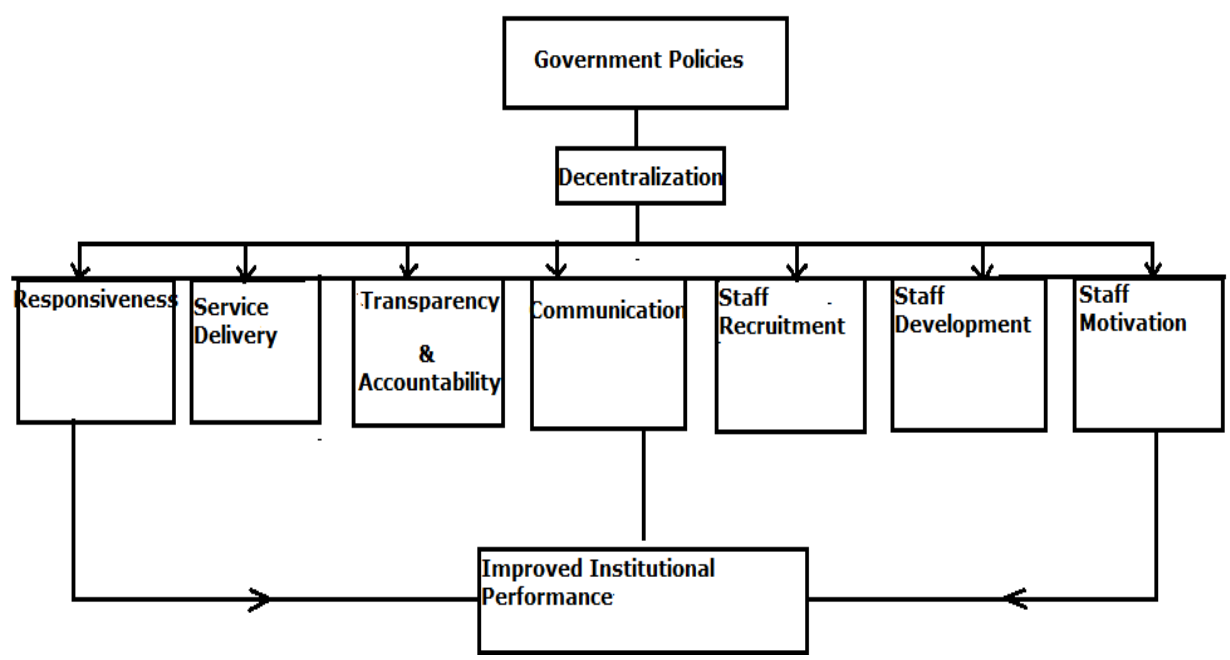

Figure 1.1 Conceptual Framework of the Study

\section{Source: Researcher}




\section{Research Design}

\subsection{Introduction}

The purpose of this chapter was to highlight the suitable methodologies to gather and analyze the data. In this study, the instruments used were questionnaires and unstructured interviews.

\subsection{Interviews (unstructured) with members of staff from which college were conducted}

\subsection{Questionnaires were administered to the sampled population}

\subsection{The target population}

This study was conducted at three teacher training Government or Public colleges, namely; CBCE (For senior secondary school teachers), KICE (For primary school teachers) and MUCE (For junior secondary school teachers).

The target group comprised members of the academic, non-academic staff and the administration. The study focused on thirty (30) people. That is ten (10) participants from each institution. Table 2.1 below shows this data.

Table 2.1 People to include in the study

\begin{tabular}{lll}
\hline Type of people & Number per college & Totals \\
\hline Administration (Principal) & 1 & 3 \\
Academic & 8 & 24 \\
Librarian & 1 & 3 \\
\hline
\end{tabular}

The target group either had prior knowledge about education decentralization in Zambia or had no knowledge at all. Simple random sampling method was used in selecting the sample.

\section{Method}

\subsection{Introduction}

This chapter comprised four sub-titles; namely research questions, research design, sampling techniques and data analysis plan. Each of these sub-titles will be explained further.

\subsection{Research Questions}

3.2.1. What has been the impact on performance of the introduction of the decentralization policy in public colleges of education?

3.2.2 Are there significant differences on the performance among the three sampled institutions?

3.2.3 How has been the role of the Government (Ministry of Education) in the three institutions since the decentralization reforms?

\subsection{Research Design}

\subsubsection{Population}

$>$ Three (3) principals/Vice principals, one from each of three institutions

$>$ Three (3) librarians, one from each institutions

$>$ Twenty-four (24) randomly selected academic staff, eight (8) from each institution. The sample was randomly chosen using the factors of gender, length of service and the number of years one served at the college

\subsubsection{Research Choice: Multi-method}

\subsubsection{Data Collection}

> Exploratory/Survey (Individual interviews and structured questionnaires)

$>$ Desk research involving getting data from books, journals, Government reports or documents and the Internet sources)

\subsubsection{Time Horizon: Cross sectional}

\subsubsection{Strategy: Survey}

\subsection{Sampling Techniques}

No sampling will be used for the following:

3.4.1 Principals, because there is only one (1) principal for each institution

3.4.2 Librarians, because there is only one (1) librarian for each institution 
However, for the academic staff, due to a fair and valid population in each institution, non-probabilistic sampling method will be used and a purposive sampling technique will be used to select the eight (8) academic staff from each institution.

\subsection{Data Analysis Plan}

Data collected will be analyzed using the computer based statistical package of social sciences (SPSS). Data will be analyzed and summarized quantitatively by way of descriptive statistics and Spearman's correlation model.

\section{Results}

\subsection{Introduction}

The purpose of this study was to investigate the performance of public colleges of education after the introduction of decentralization reforms. This chapter therefore unfolds the main findings of the study in relation to the performance variables or indicators stated earlier on. In order to investigate the issue at hand, the study addressed the following research questions:

$>$ What has been the impact on performance of the introduction of the decentralization policy in public colleges of education?

$>$ Are there significant differences on the performance among the three sampled institutions?

$>$ How has been the role of the Government (Ministry of Education) in the three institutions since the decentralization reforms?

\section{Question 1}

From the results obtained and using the performance indicators chosen, the study showed that the performance of the sampled public institutions has not improved very much after the introduction of decentralization reforms. For instance, the performance indicators, service delivery, transparency and accountability, responsiveness, efficiency and effectiveness, communication and staff motivation demonstrated that the performance of these institutions was either average or below average. That is $50 \%$ or more of the 30 respondents clearly submitted that the performance of the three colleges was just average. Despite what has been alluded to above, the performance of the three colleges on the performance indicators, quality assurance and continuous professional development was above average. Table1below shows a detailed analysis of the participants' responses to question 1 .

Table 1 Respondents response on the performance of the institutions after decentralization

\begin{tabular}{|c|c|c|c|c|c|c|c|c|}
\hline $\begin{array}{l}\text { Performance } \\
\text { Indicators (Pi) or } \\
\text { Variables }\end{array}$ & $\begin{array}{l}\text { Service } \\
\text { Delivery }\end{array}$ & $\begin{array}{l}\text { Quality } \\
\text { Assurance }\end{array}$ & $\begin{array}{l}\text { Transparency } \\
\& \\
\text { Accountability }\end{array}$ & Responsiveness & $\begin{array}{l}\text { Efficiency } \\
\& \\
\text { Effectiveness }\end{array}$ & Communication & $\begin{array}{l}\text { Continuous } \\
\text { Professional } \\
\text { Development } \\
\end{array}$ & $\begin{array}{l}\text { Staff } \\
\text { Motivation }\end{array}$ \\
\hline Very High & 7 & 3 & 4 & 4 & 4 & 4 & 5 & 3 \\
\hline High & 7 & 12 & 5 & 6 & 4 & 6 & 10 & 10 \\
\hline Average & 16 & 15 & 14 & 15 & 18 & 17 & 11 & 13 \\
\hline Below Average & 0 & 0 & 7 & 5 & 4 & 3 & 4 & 4 \\
\hline
\end{tabular}

Table 2 below aims at highlighting how strong the different performance indicators correlate with each other and how this result in a chain reaction on other performance variables and eventually impact on the performance of colleges of education. Since all the performance indicators used in the study correlate with each other positively, the research decided to focus attention on the correlations between 0.9 and 1.0 in the follow up discussion. This is because, 0.9 and 1.0 show a strong positive correlation. For instance, the performance variable service delivery, demonstrated a strong positive correlation (0.921) with the performance variable, communication and less correlation (0.699) with the performance variable, transparency and accountability. This means that, for improved service delivery, the institutions need to communicate more with the customers, itself (within the institution) and other stakeholders. On the other hand, the performance variable quality assurance showed strong positive correlation $(0.997)$ with the variables continuous professional development (0.964) and with staff motivation respectively. However, the performance indicator quality assurance, portrayed a weak positive correlation $(0.590)$ with the performance variable transparency and accountability; implying that institutions need to invest more in staff professional development or in other words, institutions need to employ well qualified academic staff. In addition, the staff must be properly enumerated and well looked after in order for them to put in their best. Furthermore, the performance indicator transparency and accountability showed strong correlation with performance variables responsiveness (0.963), efficiency and effectiveness (0.961) and communication (0.916). This entails for instance that, for the colleges to be transparent and accountable for whatever goes on in the 
college, administrators must communicate issues pertaining to college welfare in an efficient and effective manner to all stakeholders. Above all this, administrators and college staff must take responsibility for their decisions and activities undertaken by the colleges. Further still, table 2 demonstrated significant positive correlation between the performance indicator responsiveness to the performance indicators transparency and accountability (0.963), efficiency and effectiveness (0.987) and communication (0.989). This is very true because to be responsive in their day to day activities, the colleges must be transparent and accountable. For this to happen, the colleges must develop an efficient and effective channel of communication. In a similar way, the results from table 2 also established that the performance indicator continuous professional development is correlated more positively with quality assurance (0.997) and staff motivation (0.970). This is self-explanatory in the sense that, providing further academic qualifications to employees will result in a motivated staff that will be willing to provide quality education or training. In this way, customers (students) and other stakeholders will be assured of the quality of training. This eventually, will attract more customers to the institutions. Finally, the performance indicator staff motivation, demonstrated strong positive correlation with the performance variables quality assurance (0.964) and continuous professional development (0.970). As stated above, a motivated staff is an asset as it will be able to assure prospective customers (students) of the quality of products. However, quality of training or services will not come about without good and effective education of the trainers. Some authors observed that, one of the potential benefits of decentralization is increased accountability to the citizen/beneficiary, resulting in improved efficiency in the use of school resources. The improved efficiency results from two effects. One of the effects is the better match between service provided and the preferences of citizens. The other effect is increased output relative to resources or expenditures.

Therefore, from the above discussion, it can be acknowledged that the results in table 2 are extremely significant to this study; one because they assisted the researcher to appreciate the knowledge level of the respondents. That is, the researcher was able to tell whether the respondents understood the question(s) they answered with the help of table 2 . For instance, if a respondent viewed college performance indicator, service delivery as low or average, s/he should also realize that even the performance variable, communication should also score a lower value because the two complement or are related to each other. Thus, as we analyzed the responses from table 1 and table 2, we noted the following: To begin with, the low performance of colleges on the variable service delivery as indicated in table 1 meant that even the performance on the variable communication should also be low. This is clearly demonstrated in table 1 where 12 respondents rated the performance of colleges on the performance indicator, service delivery as average and 17 rated performances of colleges on the performance indicator, communication the same away. Thus, the low performance of colleges on the performance indicator, communication, entails that even performances on indicators, transparency and accountability, responsiveness and efficiency and effectiveness would reflect a similar scenario because of the strong correlation with the variable communication. Indeed, the results in Table 1, clearly confirmed this. For instance, 14 respondents rated the performance of colleges on the variable transparency and accountability as average, 15 respondents rated the performance of colleges on the indicator responsiveness, as average while 18 respondents rated the performance of colleges on the variable efficiency and effectiveness as average. Finally, table 1 indicated that 15 respondents rated the performance of the colleges on the variable quality assurance as average. This in turn implied that even variables continuous professional development and staff motivation were affected in the same manner as can be seen in table 1. In fact Makwaya's study on the performance of Education Boards at Mufulira and Chalimbana colleges of education concluded that: expected outcomes such as transparency, accountability and sense of ownership had not begun to show to any significant extent.

Having established in general that, decentralization reforms in education has not impacted significantly on the three selected colleges, the researcher then decided to investigate the impact of decentralization on each of the tree colleges in order to ascertain variations in terms of performance. Table 3 was used to investigate this fact.

Table 2 Correlation of the performance indicators

\begin{tabular}{|c|c|c|c|c|c|c|c|c|c|}
\hline & & $\begin{array}{l}\text { How do you } \\
\text { rate your } \\
\text { institution } \\
\text { performance } \\
\text { on service } \\
\text { delivery? }\end{array}$ & $\begin{array}{l}\text { How do } \\
\text { you rate } \\
\text { your } \\
\text { institution } \\
\text { performanc } \\
\text { e on } \\
\text { quality } \\
\text { assurance? }\end{array}$ & $\begin{array}{l}\text { How do you } \\
\text { rate your } \\
\text { institution } \\
\text { performance } \\
\text { on } \\
\text { transparency } \\
\& \\
\text { accountability } \\
?\end{array}$ & $\begin{array}{l}\text { How do you } \\
\text { rate your } \\
\text { institution } \\
\text { performance } \\
\text { on } \\
\text { responsiveness? }\end{array}$ & $\begin{array}{l}\text { How do you } \\
\text { rate your } \\
\text { institution } \\
\text { performance } \\
\text { on efficiency } \\
\& \\
\text { effectiveness } \\
?\end{array}$ & $\begin{array}{l}\text { How do you } \\
\text { rate your } \\
\text { institution } \\
\text { performance } \\
\text { on } \\
\text { communicatio } \\
\mathrm{n} \text { ? }\end{array}$ & $\begin{array}{l}\text { How do you } \\
\text { rate your } \\
\text { institution } \\
\text { Performance on } \\
\text { continuous } \\
\text { professional } \\
\text { development? }\end{array}$ & $\begin{array}{l}\text { How do you } \\
\text { rate your } \\
\text { institution } \\
\text { performance } \\
\text { on staff } \\
\text { motivation? }\end{array}$ \\
\hline How do you rate your & Pearson Corr & 1 & 0.854 & 0.699 & 0.853 & 0.864 & $0.921^{*}$ & 0.811 & 0.784 \\
\hline institution & Sig (2 tailed). & & 0.146 & 0.301 & 0.147 & 0.136 & 0.079 & 0.189 & 0.216 \\
\hline
\end{tabular}




\begin{tabular}{|c|c|c|c|c|c|c|c|c|c|}
\hline $\begin{array}{l}\text { performance on } \\
\text { service delivery? }\end{array}$ & $\mathrm{N}$ & 4 & 4 & 4 & 4 & 4 & 4 & 4 & 4 \\
\hline How do you rate your & Pearson Corr & 0.854 & 1 & 0.590 & 0.774 & 0.700 & 0.824 & $0.997^{* *}$ & $0.964^{*}$ \\
\hline institution & Sig (2 tailed). & 0.146 & & 0.410 & 0.226 & 0.300 & 0.176 & .003 & .036 \\
\hline $\begin{array}{l}\text { performance on } \\
\text { quality assurance? }\end{array}$ & $\mathrm{N}$ & 4 & 4 & 4 & 4 & 4 & 4 & 4 & 4 \\
\hline How do you rate your & Pearson Corr & 0.699 & 0.590 & 1 & $0.963^{*}$ & $0.961^{*}$ & $0.916^{*}$ & 0.568 & 0.724 \\
\hline institution & Sig (2 tailed). & 0.301 & 0.410 & & 0.037 & 0.039 & 0.084 & 0.432 & 0.276 \\
\hline $\begin{array}{l}\text { performance on } \\
\text { transparency \& } \\
\text { accountability? }\end{array}$ & $\mathrm{N}$ & 4 & 4 & 4 & 4 & 4 & 4 & 4 & 4 \\
\hline How do you rate your & Pearson Corr & 0.853 & 0.774 & $0.963^{*}$ & 1 & $0.987^{*}$ & $0.989^{*}$ & 0.749 & 0.851 \\
\hline institution & Sig (2 tailed). & 0.147 & 0.226 & 0.037 & & 0.013 & 0.011 & 0.251 & 0.149 \\
\hline $\begin{array}{l}\text { performance on } \\
\text { responsiveness? }\end{array}$ & $\mathrm{N}$ & 4 & 4 & 4 & 4 & 4 & 4 & 4 & 4 \\
\hline How do you rate your & Pearson Corr & 0.864 & 0.700 & $0.961^{*}$ & $0.987^{*}$ & 1 & $0.981^{*}$ & 0.664 & 0.765 \\
\hline institution & Sig (2 tailed). & 0.136 & 0.300 & 0.039 & 0.013 & & 0.019 & 0.336 & .0235 \\
\hline $\begin{array}{l}\text { performance on } \\
\text { efficiency \& } \\
\text { effectiveness? }\end{array}$ & $\mathrm{N}$ & 4 & 4 & 4 & 4 & 4 & 4 & 4 & 4 \\
\hline How do you rate your & Pearson Corr & $0.921^{*}$ & 0.824 & $0.916^{*}$ & $0.989^{*}$ & $0.981^{*}$ & 1 & 0.794 & 0.861 \\
\hline institution & Sig (2 tailed). & 0.079 & 0.176 & 0.084 & 0.011 & 0.019 & & 0.206 & 0.139 \\
\hline $\begin{array}{l}\text { performance on } \\
\text { communication? }\end{array}$ & $\mathrm{N}$ & 4 & 4 & 4 & 4 & 4 & 4 & 4 & 4 \\
\hline How do you rate your & Pearson Corr & 0.811 & $0.997^{\text {**k }}$ & 0.568 & 0.749 & 0.664 & 0.794 & 1 & $0.970^{*}$ \\
\hline institution & Sig (2 tailed). & 0.189 & 0.003 & 0.432 & 0.251 & 0.336 & 0.206 & & 0.030 \\
\hline $\begin{array}{l}\text { performance on } \\
\text { continuous } \\
\text { professional } \\
\text { development? }\end{array}$ & $\mathrm{N}$ & 4 & 4 & 4 & 4 & 4 & 4 & 4 & 4 \\
\hline How do you rate your & Pearson Corr & 0.784 & $0.964^{*}$ & 0.724 & 0.851 & 0.765 & 0.861 & $0.970^{*}$ & 1 \\
\hline institution & Sig (2 tailed). & 0.216 & 0.036 & 0.276 & 0.149 & 0.235 & 0.139 & 0.030 & \\
\hline $\begin{array}{l}\text { performance on staff } \\
\text { motivation? }\end{array}$ & $\mathrm{N}$ & 4 & 4 & 4 & 4 & 4 & 4 & 4 & 4 \\
\hline
\end{tabular}

* Correlation is significant at the 0.05 level (2-tailed).

** Correlation is significant at the 0.01 level (2-tailed)

\section{Question 2}

The objective of this question was to find out how decentralization reforms have impacted on each of the sampled colleges of education. This was very cardinal as question one was only aimed at investigating the impact of decentralization on colleges in general. This however did not highlight or demarcate how decentralization reforms impacted on individual colleges. This being the case therefore, analysis of responses from question 2 would provide an insight on the performance of each college of education. This would further guide the researcher to make informed judgments on how decentralization reforms have impacted on the performance of colleges. To answer question 2 , the researcher used table 3 below.

Table 3. Respondents responses on the performance of individual institutions after Decentralization reforms

\begin{tabular}{|c|c|c|c|c|c|c|c|c|c|c|c|c|}
\hline \multirow{4}{*}{$\begin{array}{l}\text { PERFORMANCE } \\
\text { INDICATORS } \\
\text { (PI) OR } \\
\text { VARIABLES }\end{array}$} & \multicolumn{12}{|c|}{ RESPONSE TYPE } \\
\hline & \multicolumn{4}{|c|}{ CBCE } & \multicolumn{4}{|c|}{ KICE } & \multicolumn{4}{|c|}{ MUCE } \\
\hline & Very & High & Average & Below & Very & High & Average & Below & Very & High & Average & Below \\
\hline & High & & & Average & High & & & Average & High & & & Average \\
\hline Service Delivery & 1 & 3 & 6 & & 3 & 1 & 6 & & 3 & 3 & 4 & \\
\hline Quality Assurance & 1 & 4 & 5 & & 1 & 3 & 6 & & 1 & 3 & 6 & \\
\hline Transparency\& & 1 & & 5 & 4 & 2 & 2 & 4 & 2 & 1 & 3 & 5 & 1 \\
\hline Accountability & & & & & & & & & & & & \\
\hline Responsiveness & 1 & 1 & 5 & 3 & 2 & 2 & 4 & 2 & 1 & 3 & 6 & \\
\hline
\end{tabular}




\begin{tabular}{|c|c|c|c|c|c|c|c|c|c|c|c|c|c|}
\hline Efficiency & $\&$ & 1 & & 6 & 3 & 2 & 2 & 5 & 1 & 1 & 2 & 7 & \\
\hline \multicolumn{14}{|l|}{ Effectiveness } \\
\hline Communication & & 1 & & 8 & 1 & 2 & 3 & 4 & 1 & 1 & 3 & 5 & 1 \\
\hline Continuous & & 1 & 2 & 5 & 2 & 2 & 5 & 2 & 1 & 2 & 3 & 4 & 1 \\
\hline \multicolumn{14}{|l|}{ Professional } \\
\hline \multicolumn{14}{|l|}{ Development } \\
\hline \multicolumn{14}{|l|}{ (CPD) } \\
\hline Staff Motivation & & 1 & 3 & 4 & 2 & 1 & 4 & 4 & 1 & 1 & 3 & 5 & 1 \\
\hline
\end{tabular}

\section{Question 3}

This question was answered using data in tables 4, 5 and 6. The question was cardinal to the study because it helped to place the way public institutions are performing in perspective. That is, to understand whether the way public colleges are performing in the new era of decentralization could be attributed to Government's role or not. Government's role as used in this study implies Government influence or control in the operations of the colleges.

In table 5 below, the indicators quality assurance, responsiveness and transparency and accountability, demonstrated that Government's role was almost the same in the three colleges. For instance, respondents from CBCE rated government's role in quality assurance as follows: I for high, 7 for average and 2 as below average. In case of KICE, 1 respondent rated it high, 7 indicated average and 2 said below average. For MUCE, 1respondent rated government's role as high, 6 said it was average while 3 indicated below average. Nevertheless, responses on indicators efficiency and effectiveness, student enrolment and staff recruitment showed varied results. Results from CBCE respondents clearly show that government's role is insignificant on these indicators. To the contrary, results from respondents from KICE show that of the three indicators, government's role was felt more in student enrolment and staff recruitment and to a less extent on efficiency and effectiveness. On the other hand, results from MUCE indicated that government's role was felt more on the indicators student recruitment and efficiency and effectiveness.

Thus, the picture portrayed from the analysis seem to suggest that the average performance observed in the analysis of questions 1 and 2 cannot be attributed to Government's role in these institutions, rather, the average performance of these institutions may be the influence from other factors such as internal factors which the study will investigate.

Table 5 Government role in individual institution after Decentralization reforms

\begin{tabular}{|c|c|c|c|c|c|c|c|c|c|c|c|c|}
\hline \multirow{3}{*}{$\begin{array}{l}\text { Performance } \\
\text { Indicators (Pi) Or } \\
\text { Variables }\end{array}$} & \multicolumn{12}{|c|}{ RESPONSE TYPE } \\
\hline & \multicolumn{4}{|c|}{ CBCE } & \multicolumn{4}{|c|}{ KICE } & \multicolumn{4}{|c|}{ MUCE } \\
\hline & $\begin{array}{l}\text { Very } \\
\text { High }\end{array}$ & High & Average & $\begin{array}{c}\text { Below } \\
\text { Average }\end{array}$ & $\begin{array}{l}\text { Very } \\
\text { High }\end{array}$ & High & Average & $\begin{array}{c}\text { Below } \\
\text { Average }\end{array}$ & $\begin{array}{l}\text { Very } \\
\text { High } \\
\end{array}$ & High & Average & $\begin{array}{r}\text { Below } \\
\text { Average }\end{array}$ \\
\hline Quality Assurance & & 1 & 7 & 2 & & 1 & 7 & 2 & & 1 & 6 & 3 \\
\hline Responsiveness & & & 6 & 4 & & 2 & 8 & & & 1 & 7 & 2 \\
\hline Transparency\& & & 1 & 6 & 3 & & 1 & 6 & 3 & & 1 & 8 & 1 \\
\hline Accountability & & & & & & & & & & & & \\
\hline Efficiency & & 1 & 5 & 4 & & 3 & 4 & 3 & & 3 & 3 & 4 \\
\hline Effectiveness & & & & & & & & & & & & \\
\hline Student Enrolment & & & 7 & 3 & & 6 & 4 & & & 3 & 7 & \\
\hline Staff Recruitment & & & 2 & 8 & & 5 & 3 & 2 & & 1 & 6 & 2 \\
\hline
\end{tabular}

Nevertheless, to be certain about the results just discussed, a further analysis was performed, the correlation analysis, on the raw data in tables 4 and 5 and the results are presented in table 6.

Table 6. Correlations of the Performance Variables

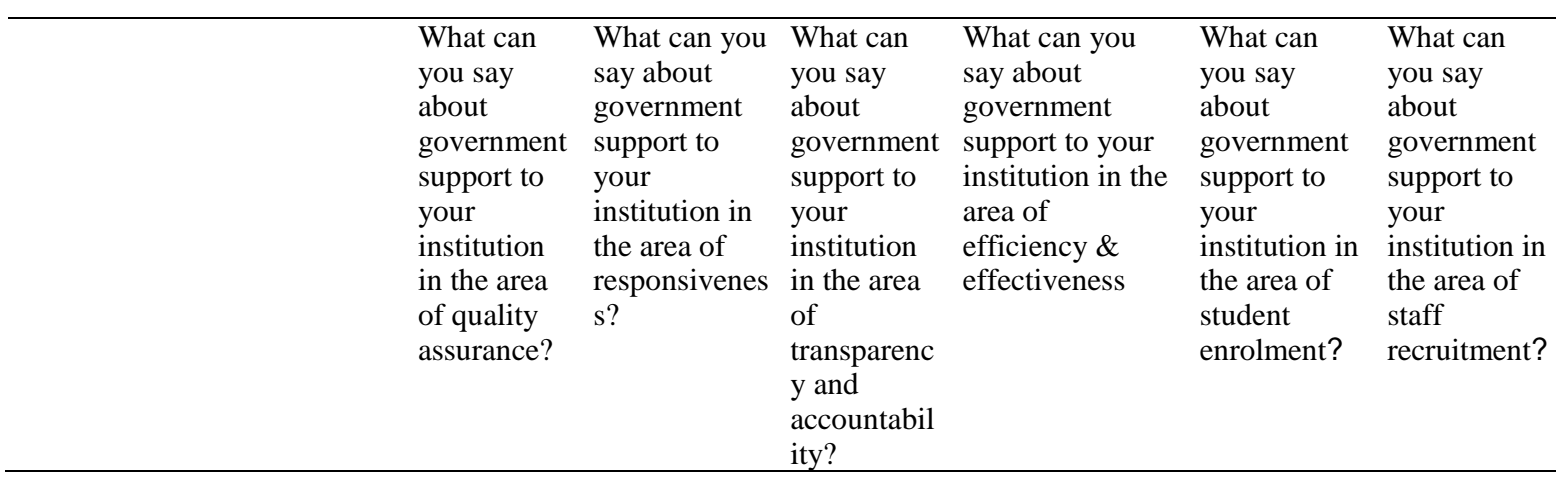




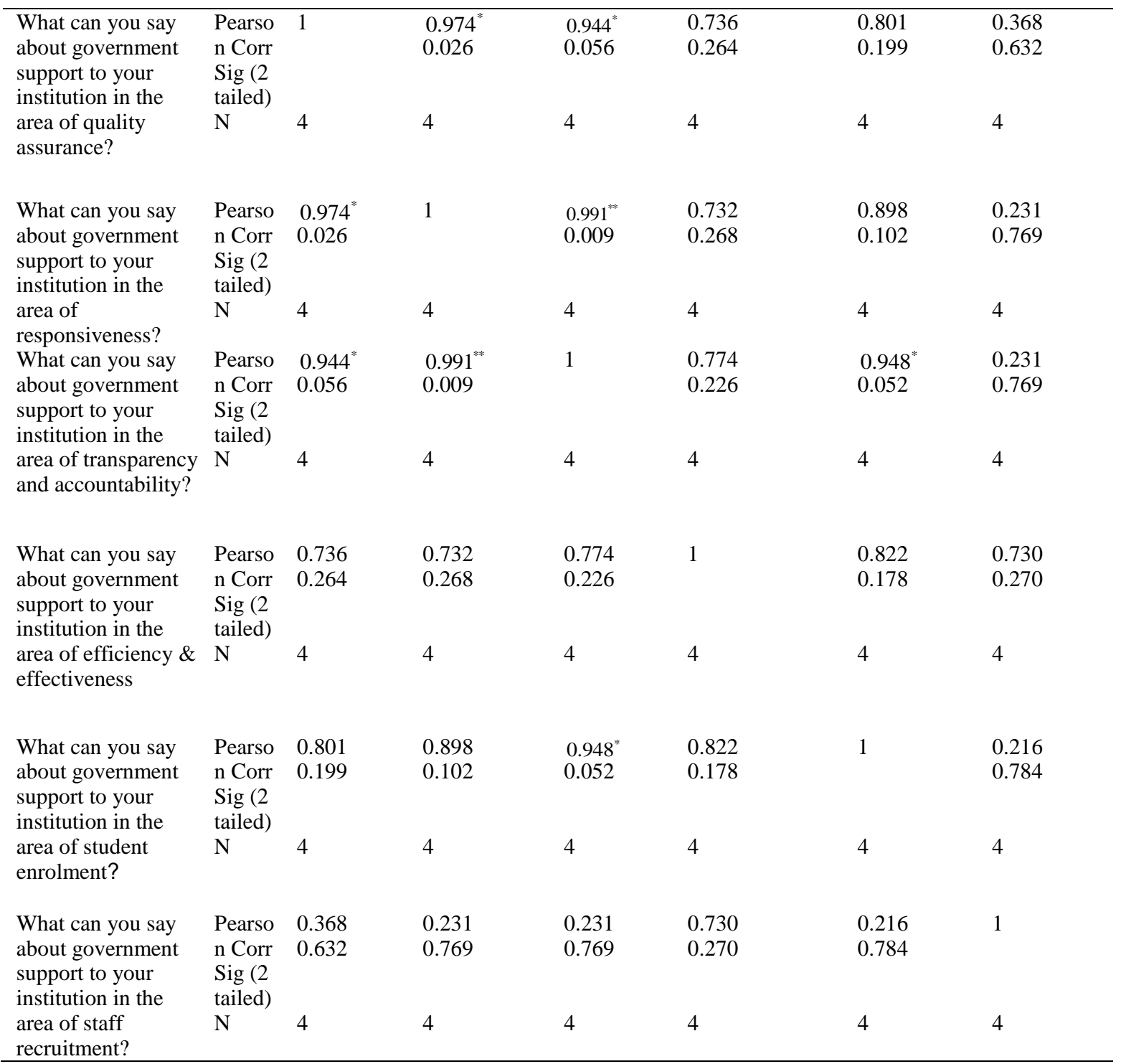

* Correlation is significant at the 0.05 level (2-tailed).

** Correlation is significant at the 0.01 level (2-tailed).

To start with, the results from table 6 demonstrated clearly that the performance indicators, staff recruitment and efficiency and effectiveness have weak positive correlation ratios with the other four performance indicators. For example, table 6 shows that the correlation between the performance indicator, efficiency and effectiveness and quality assurance is 0.736 and the $\rho$ value of 0.264 at the level of significance of 0.05 . Similarly, the correlation of 0.730 was recorded between the performance indicator efficiency and effective and staff recruitment, representing a $\rho$ value of 0.270. Apart from this, data from table 6 also indicate that the performance indicator, staff recruitment had no relation or had very weak positive correlation ratio with the other variables. For instance, table 6 demonstrated that the correlation between the performance indicators staff recruitment and student enrolment was 0.216 and $\rho$ value of 0.784 at the level of significance of 0.05. Similarly, the Pearson correlation between staff recruitment and either responsiveness or transparency and accountability, was 0.231 and $\rho$ value of 0.769 at 0.05 significance level. In fact the results in table 6 shows that the higher the $\rho$ value the lower the correlation between variables hence less association. Therefore, from the fore-going discussion, it can be observed that Government has little or no significant role to play when it comes to ensuring efficiency and effectiveness as well as staff recruitment in colleges of education. Nevertheless, table 6 demonstrated significant correlation between performance indicators quality assurance, responsiveness, student enrolment and transparency and accountability. For instance, the performance indicator quality assurance demonstrated strong positive correlation ( 0.974 ; at 0.05 significance level) with the variable responsiveness and a correction of $(0.944$; at 0.05 significance level) with the variable transparency and accountability. Similarly, the performance indicator, responsiveness also showed strong positive correlation (0.991; at 0.001 significance level) with the variable transparency 
and accountability and $\rho$ value of 0.009 . Finally, the performance indicator transparency and accountability showed strong positive association or correlation (0.948; at 0.05 significance level) with the variable student enrolment and $\rho$ value of 0.052 . Now the results from table 4 clearly show that, Government influence in the areas of responsiveness, quality assurance and transparency and accountability is very minimal, if not insignificant. For instance, from table 4, $97 \%$ (29) respondents felt that Government's role in the issues of quality assurance in public colleges of education had drastically reduced. In other words, colleges of education have more say in quality assurance issues than it was before the introduction of decentralization reforms.

\section{Discussion}

\subsection{Introduction}

The study was conducted to establish the performance of public colleges of education since the launch of the decentralization policy in the education system. The study was guided by three research questions:

- What has been the impact on performance of the introduction of the decentralization policy in public colleges of education?

- Are there significant differences on the performance among the three sampled institutions?

- How has been the role of the Government (Ministry of Education) in the three institutions since the decentralization reforms?

In answering the questions above, the study was guided by the following performance variables: Service delivery, quality assurance, transparency and accountability, responsiveness, efficiency and effectiveness, communication, continuous professional development and staff recruitment. These performance indicators or variables were selected because they are the main reasons or results of implementing decentralization policies. Asghar (2005), outlined the benefits of educational decentralization as considerable improvement in transparency, administrative efficiency, parental participation, financial management, the quality and accessibility of services and the development of political responsibility in general. Thus, the discussions that follow will illuminate on the findings of the research in Zambia.

\subsection{Discussion of the Performance Variables}

\subsubsection{Service Delivery}

Improved service delivery is one of results of decentralization reforms. However, for the three sampled colleges of education, the study has found that service delivery was still at its infancy. This implies that, service delivery in the three colleges is still low. Since service delivery entails, by our definition, the manner in which colleges are delivering the teaching or the programmes to the clients, it means that there is a general dissatisfaction by students, parents and guardians and other stakeholders in the manner colleges are conducting the teaching and more so how programmes are being organized. Table 1 for instance, shows that 16 respondents out of 30 rated the performance of the three colleges on the variable service delivery as average, representing 53\%. Nevertheless, as individual institutions, MUCE seems to be doing better than $\mathrm{CBCE}$ and $\mathrm{KICE}$ as demonstrated in table 3. Respondents rated the performance of the three colleges in this manner because of the following reasons:

- The number of students has increased in colleges while classroom space has remained constant resulting in large or overcrowded classrooms. Consequently, teaching such classes has become a challenge. This has eventually resulted in poor service delivery of the teaching and learning in the three colleges. Nonetheless, the extent to which service delivery is affected differs from college to college. This is why colleges such as MUCE have gone a mile ahead of others by constructing some classroom blocks in order to alleviate or reduce the mentioned problem. Apart from having overcrowded classrooms, lecturers are also over stretched because of packed time-tables. In other words, lecturers rarely have space to research because they are always teaching. Ultimately, because lecturers are over worked, lesson delivery is negatively affected as well.

\subsubsection{Quality Assurance}

Quality assurance is another very important component of educational decentralization policy in Zambia. From the earlier discussions in the study, it was shown that quality assurance is positively and strongly correlated with staff motivation and continuous professional development. On the other hand, it is less positively correlated with responsiveness and transparency and accountability. Generally data indicated that in the three colleges of education, there have been a lot of efforts targeted at quality assurance. This is being achieved through involving external organizations or institutions in teaching and assessment issues. For instance, the three institutions have or are working in association with the University of Zambia (UNZA) where UNZA is providing guidance in terms assessment issues. Furthermore, $\mathrm{CBCE}$ and Copperbelt University (CBU) signed a memorandum of understanding where they promised to work together in matters related to general education and quality assurance issues. Apart from this, there is a lot internal 
effort being made (through CPD activities) to improve the quality of teaching practices by the lecturers and the product (students) graduating from these colleges. While these are recognizable efforts being undertaken by colleges to ensure quality issues in institutions of learning, very little is being done by college managements and boards to provide incentives for lecturers and other staff. For instance, there is no deliberate policy in the colleges to support lecturers pursuing further studies such that, when the lecturers graduate, they rarely stay on. In the same vein, College Boards and College Managements hardly provide monitory and other important incentives to members of staff. In this way, it becomes difficulty to attract qualified staff to work in the colleges. Some authors have argued that, decentralization has the potential to improve service delivery and education quality. From the fore-going discussion, the study has discovered that the three colleges have recognized the importance of quality assurance and therefore efforts are being made in the area of CPD. However, the colleges have no written policy regarding staff development.

\subsubsection{Transparency and Accountability}

Transparency and accountability was defined earlier on as the openness of the management in each of the three colleges to accept criticisms. The question being asked is 'Do managers in the three colleges listen, for example, to customers' complaints and act on their concerns?" So, the management style exhibited in each of the colleges determines how flexible or rigid the college management will be. Thus, if we look at data in tables 1 and 3, it's very clear that the picture being portrayed for the three colleges is very gloomy. This is to say that, the three institutions have not performed very well on the performance variable, transparency and accountability. Data in table 1 showed that, the three colleges were operating at below 50\%. This means that, college administration and/or the College Boards are not as transparent as they are expected to be. Now, since we know from table 2 that, transparency and accountability have strong and positive correlation with responsiveness, efficiency and effectiveness and communication, we can also argue that the three sampled colleges of education do not communicate efficiently and effectively with students, guardians, themselves and other stakeholders. Table 3 clearly demonstrated that, in terms of individual performance, the least performance on the variable transparency and accountability was recorded by CBCE. For example, out of 10 respondents, 9 rated the performance of the college on transparency and accountability as either average or below average, representing $90 \%$ while the remaining $10 \%$ rated the performance as above average. To the contrary, 6 respondents each from KICE and MUCE rated the performance of their colleges on this variable as average or below average whereas $40 \%$ rated the performance as above average. Makwaya (2004) argued that expected outcomes such as transparency, accountability and sense of ownership had not started to show any significant extent.

\subsubsection{Responsiveness}

In this study, responsiveness has been defined as the readiness or willingness of college administrators to be accountable (answerable) for their decisions.

The results from the research show that, of the three colleges, only MUCE seems to be more responsive in its day-to-day operations. But even then, the overall picture is not impressive. This shows lack of initiative by college administrators at CBCE and KICE to take advantage of decentralization and become more creative and enterprising. Instead they are still waiting to get instructions from the ministry headquarters and hence running away from responsibility when things go wrong in their institutions. In fact, in these colleges, the board members and the college management do not work together and because of that it becomes very difficult to be part of certain decisions. Bowasi (2007) observed that, some of the board members were not free to answer questions as they did not want to contradict their principals or present a negative picture of their college board..

\subsubsection{Communication}

According to our definition in this study, communication refers to internal and external communication; the way colleges associate or relate within themselves and with the external community. Already, we have established that efficient and effective communication is lacking in the three colleges. College managements are not involving their staff meaningfully in important activities. The creation of college boards has not made the situation any better. It was observed by (MOE, 1996) that communication does not exist in Zambia, between schools, colleges and communities. Makwaya (2004) added that, failure of college authorities and board members to work together indicated by lack of meetings, drew attention to a lack of a shared vision of what the role of the education boards in teacher education is. Thus, in the three colleges sampled, as indicated in table 3, only MUCE seems to be doing fairly well on communication.

\subsubsection{Efficiency and Effectiveness}

Efficiency and effectiveness, according to this study has been defined as the timely and quality delivery of programmes. Now from the findings of the study, the three colleges have not performed very well on this performance variable. Table 3 demonstrated that out of 10 respondents from CBCE, 1 respondent rated the college's performance as very high, 6 
rated it average while 3 indicated below average. On the other hand, 4 respondents from KICE rated the college's performance on this indicator as above average while 5 rated it at average and only 1 indicated below average. Finally, 3 respondents from MUCE rated the college's performance on efficiency and effectiveness as above average while 7 stated average. From this analysis the general picture is that, the three colleges have not performed well on this variable. This is as expected because of the strong correlation this variable has with the performance variables; communication, transparency and accountability and responsiveness. Since the performance of the three colleges on these variables has been average, we expect the same results for the performance indicator, efficiency and effectiveness.

\subsubsection{Continuous Professional Development}

By Continuous Professional Development, we mean college policy on staff development: in terms of improving classroom practice and also on staff upgrading of their qualifications. From the findings of the study, colleges are trying to organize internal CPD activities to improve lecturers' classroom teaching practices. However, no deliberate policy exists in these colleges to sponsor lecturers who want to pursue further studies. Colleges are always complaining about poor funding. (Makwaya) observed that the only role boards played was to recommend for study leave for ambitious individuals.

\subsubsection{Staff motivation}

Staff motivation was defined in this study as the reward system or incentives the college has put in place for hard working and performing staff.

Motivation, in whatever form, is a necessary ingredient in improving staff performance. Now at the three colleges sampled, staff motivation has not been embraced as part of improving organization performance. Makwaya (2004) argued that promotions are still the preserve of the administration represented by the principal and the provincial Education Officer (P.E.O) who recommend candidates for promotion to the teaching service.

\subsubsection{Staff recruitment}

Staff recruitment entails the ability of college administration to lobby or employ suitable and well qualified academic staff

Employing suitably qualified and competitive employees is one of the most important things that an institution can do. This is so because having qualified staff gives customers confidence in the institution. Previously, that is before decentralization, government was responsible for employing the teaching staff in colleges. However, with the advent of decentralization, colleges have been tasked to source and employ staff to teach in the colleges. The results in table 5, clearly demonstrated this fact. Of the three colleges under study, CBCE and MUCE seem to be performing well on this performance variable unlike KICE. AT KICE, there is much dependence on government to send lecturers to the college as opposed to sourcing for staff. On the hand, CBCE and MUCE seem to be proactive on this variable in that they are able to source the needed staff. At CBCE, the college management and the board have been employing academic staff on contract to teach during distance education sessions. However, these efforts are being hampered by inadequate funds and bureaucratic nature of the Teaching Serving to recommend the identified staff.

\section{Research conclusion and recommendations}

\subsection{Introduction}

This research set out to investigating the performance of three public colleges of education; CBCE, KICE and MUCE since the introduction of decentralization policy in the ministry of education. This was done to find out whether colleges are performing better than before the introduction of decentralization reforms. After a critical analysis of the results, the researcher was able to conclude the research as follows:

\subsection{Conclusion}

The research has shown that decentralization leads to improved service delivery, transparency and accountability, efficiency and effectiveness. Moreover, institutions become more responsive in the way they conduct business and themselves. All these put together, result in high performance of institutions. In the same way, as government lessens its influence, it gives much more freedom to colleges and boards as has been revealed by the data collected and summarized in table 5. The conclusion of this study is that the average performance of the colleges under study could not be attributed to government interference or role in these institutions, but it is as a result of internal problems or frictions within each of the sampled colleges. Therefore, the conclusion of the study was drawn by analyzing internal factors from the findings as follows: Service delivery is very cardinal in any organization whether private or public like the three colleges under discussions. This is what government recognized and wishes to see in the decentralized public colleges. This meant that government colleges should be able to compete and offer quick services to the customers. However, despite the decentralization of colleges service delivery has not improved very much. According to the data 
obtained in sampled colleges this is at just about 50\% regardless the fact that government has relinquished about $79 \%$ freedom for the colleges to design and sort out quality assurance issues of their colleges. This is not a good picture and it must change if public colleges have to compete very effectively in the education provision. College administrators must also realize that people (customers) are demanding for quality services and products in exchange for their money. Therefore, colleges of education must start working seriously on quality issues otherwise they will find themselves out of business. Since there are internal problems peculiar to individual colleges, there is need for each College Board to sit with all stake holders in the college and sought out quality assurance issues.

Transparency and accountability are the engines of good governance and therefore good administration. Decentralization demands that an organization becomes more transparent and accountable for it to perform very well. Now data collected from the three colleges have shown that government has decentralized the issues of transparency and accountability to about $86 \%$. This means that government is encouraging colleges to 'clean their houses' by leaving issues of transparency and accountability to be dealt by colleges themselves. In other words, the government is demanding that colleges become more transparent and accountable without being forced by government. The data in table 1 show that transparency and accountability issues are being addressed at $47 \%$. There is need for college managements to emulate government and try to be more transparent and accountable in the way they are managing colleges in terms of both financial and human resources. Like transparency and accountability, college managements are not showing responsiveness in the way they deal with college issues. They still believe that government is still responsible to make certain decisions and even tell them how to manage the colleges. Despite government direct involvement reducing to as low as $30 \%$, colleges have not taken advantage of this as the level of responsiveness is currently as low as 33\%: Refer to table 4 and table 1respectively. This demonstrates that college administrators are not so keen in taking initiatives in order to avoid taking responsibilities if things go wrong. However, there is need to encourage college administrators to be more courageous so as to make them more responsive for activities in their colleges. Another variable is not being addressed adequately is communication. In the three colleges included in the study, this has come out as a very serious hindrance and a threat to decentralisation of education. Managements are not communicating with members of staff on important issues of the colleges. In the same vein, College Boards are not also communicating with the staff, students and members of the communities. As a result of this, there is too much mistrust between college boards and the members of the community. Thus, there need for college management and board to learn to communicate efficiently and effectively with all the members of communicate; students members of staff, parents and other community.

In a similar way, the study find out those issues to do with efficiency and effectiveness, staff motivation and staff recruitment in the sampled colleges are not being adequately addressed. Table explains much more on how respondents felt about the way these issues are being addressed. In general, the research has find that all the eight performance indicators are not sufficiently addressed in the three colleges. Consequently, this has impacted negatively on the performance of the colleges. Hence, there is need to urgently deal with this situation if the objectives of government of devolving powers to local units will be achieved.

Finally, the study has established that there is no significant impact of decentralization policy on the performance of selected public colleges due to several factors outlined above. Hence, the hypothesis that the introduction of decentralisation reforms in public colleges of education has not impacted significantly on their performance is accepted.

\subsection{Recommendations}

In order for decentralization reforms to yield the desired results, in public colleges the researcher would like to recommend the following:

\subsubsection{Principals must undergo training in management.}

The government should ensure that principals running public colleges are given or undergo training in management to equip them with skills relevant to colleges in the $21^{\text {st }}$ century. In fact this was one of things outlined in the education decentralisation reforms. Among the three institutions considered for this study, no principal was trained in management course. Nevertheless, the current principal of MUCE has a master degree in business administration (MBA) which she studied on her own. Because of this, her managerial skills are far much better than the two other principals from KICE and CBCE. Therefore, there is need for all principals to be trained for decentralisation to work effectively.

\subsubsection{The College Boards}

When educational decentralisation policy was being launched in institutions of learning, college boards were seen as vehicles through which the local voice could be heard. It is hoped that through decentralisation, there would be an enhancement of community participation in the running of schools and other educational institutions, such as colleges of education. Makwaya (2004) argued that, to achieve these objectives of decentralisation in teacher education, a need 
arose to design a mechanism through which the objectives and all that they entail could be actualized, hence the creation of Teacher Education Boards. As already pointed out, college boards in the three colleges are not performing as expected. Consequently, the researcher would like to recommend that:

- The composition and selection of board members be re-visited. Perhaps, an inclusion of educational qualification for board members would help to have members who will be able to articulate issues and thereby add value to the boards.

- The ministry of education should ratify the list of selected board members and also government should be more involved in the operations of college boards

- Should be empowered to overrule or discipline the principal and even recommend for his transfer to the teaching service.

\section{Acknowledgements}

I would like to express my thanks to my supervisor, Mr. M.K Banda for his support, guidance, advice and encouragement. His kind personality and patience increased my motivation on every step of my study.

I would also like to express my heart felt gratitude to Dr. T.K. Taylor for his understanding as Dean of the school of Graduate Studies.

Finally, I wish to thank members of staff from the three colleges for the different contributions they rendered in order to enable me successfully conduct this study.

\section{References}

Abisamra, N. (2001). Educational Decentralization in Mexico. Beruit: American University press.

Adamolekun, L. (1999). Decentralization, Sub-national Governmental Relations. Boulder: West view Press

Aryee, S. (1994a). The Effectiveness of Decentralization Policy in Ghana.

Asghar, M. (2005). Decentralization in Education: National Policies \& Practices. Paris: UNESCO

Astiz, M. F. et al (2002). Slouching towards Decentralization: Consequences of Globalization for curricular control in National Education Systems. Comparative Education Review, 1(1).

Bray, M. (1985). Education and Decentralization in less Developed Countries: A Comment on General Trends, Issues and Problems with particular reference to Papua New Guinea. Journal of Comparative Education, 21(20).

Cheema e.tal (1985).Decentralization in Developing Countries: A review of recent experience. Washington D.C: World Bank

Di-Gropell, O. E. (1999). Educational Decentralization Models in Latin America. ECLAC Review, 68.

Hanson, E. (1998). Strategies of Educational Decentralization: key questions and core issues. Journal of Educational Administration, 36(2).

Ho, W. K., \& Gopinathan, S. (1999). Recent Developments in Education in Singapore. Journal of School Effectiveness and School Improvement, 10(1).

Kelly, M. J. (1999). Origins and Development of Education in Zambia. Lusaka: Image Publishers.

Lee, M. H. \& Gopinathan, S. (2003). Centralized Decentralization of Higher Education in Singapore, in Mok, K.H. Centralization \&Decentralization: Educational Reforms and Changing Governance in Chinese Societies.

Hong Kong:The University of Hong Kong press.

Mc Ginn, N., \& Welsh, T. (1999). Decentralization of Education: Why, When, What and How? Paris: UNESCO.

Mwanakatwe, J. (1968). The Growth of Education in Zambia since independence. Nairobi, Oxford University Press.

Naidoo, J. (2005). Education Decentralization in Africa: Great Expectations and Unfulfilled promises in David, P. Barker, e tal. Washington D.C: Emerald Group Ltd.

Snelson, P. (1974). Educational Development in Northern Rhodesia: 1883 - 1945. Lusaka: Zambia Educational publishing House (ZEPH).

\section{Unpublished Theses and dissertations}

Bowasi, D. S. (2007). The Role of student representatives on Education Boards: The case of Zambia Institute of Special Education, Copperbelt College of Education and Kitwe College of Education. (Unpublished master's thesis). University of Zambia, Lusaka, Zambia. 
Makwaya, M.C. (2005). Decentralization. (Unpublished master's thesis). University of Zambia, Lusaka, Zambia

\section{Documents}

Ministry Of Education, (2005). Principals of Educational Boards Government \& Management: Education Boards Services, Lusaka

Ministry of Education, (1996). National Policy on Education; Educating Our Future.

National Implementation Framework 2008 - 2010: Ministry of Education, Lusaka

South African Constitution (1996)

Zambia's Strategic plan (2003- 2007)

\section{Internet sources}

Hanson, E. (2000). Educational Decentralization around the Pacific Rim.

From http://www1.worldbank.org/education/globaleducattionreform/Hanson\%20Editorial.pdf

\section{Paper / Speech}

Husain, S. (2006). Devolution for empowering the poor: Institutions, Norms and Powers.

Paper presented at the $22^{\text {nd }} A G M$ \& Conference of Pakistan Society of Department of Economics held on 19th - 21st December 2006 in Lahore

Tan, K.Y.T (1986). Economic changes and formation of education policy

Speech delivered at the Nanyanya Technological Institute Forum

American Psychological Association. (1972): Ethical standards of psychologists. Washington, DC: American Psychological Association.

Appendix Coding of Variables

\begin{tabular}{|c|c|c|}
\hline Variable & Variable label & Code \\
\hline$X_{1}$ & Service Delivery & $\begin{array}{l}\text { Below average }=1, \text { Average }=2, \\
\text { High }=3, \text { Very high }=4\end{array}$ \\
\hline$X_{2}$ & Quality Assurance & $\begin{array}{l}\text { Below average }=1, \text { Average }=2, \\
\text { High }=3 \text {, Very high }=4\end{array}$ \\
\hline$X_{3}$ & Transparency \& Accountability & $\begin{array}{l}\text { Below average }=1, \text { Average }=2, \\
\text { High }=3 \text {, Very high }=4\end{array}$ \\
\hline$X_{4}$ & Responsiveness & $\begin{array}{l}\text { Below average }=1, \text { Average }=2, \\
\text { High }=3 \text {, Very high }=4\end{array}$ \\
\hline$X_{5}$ & Efficiency \& Effectiveness & $\begin{array}{l}\text { Below average }=1, \text { Average }=2, \\
\text { High }=3 \text {, Very high }=4\end{array}$ \\
\hline$X_{6}$ & Communication & $\begin{array}{l}\text { Below average }=1, \text { Average }=2, \\
\text { High }=3 \text {, Very high }=4\end{array}$ \\
\hline$X_{7}$ & $\begin{array}{l}\text { Continuous } \\
\text { Development }\end{array}$ & $\begin{array}{l}\text { Below average }=1, \text { Average }=2, \\
\text { High }=3 \text {, Very high }=4\end{array}$ \\
\hline$X_{8}$ & Staff motivation & $\begin{array}{l}\text { Below average }=1, \text { Average }=2, \\
\text { High }=3, \text { Very high }=4\end{array}$ \\
\hline$X_{9}$ & Staff recruitment & $\begin{array}{l}\text { Below average }=1, \text { Average }=2, \\
\text { High }=3 \text {, Very high }=4\end{array}$ \\
\hline$X_{10}$ & Student enrolment & $\begin{array}{l}\text { Below average }=1, \text { Average }=2, \\
\text { High }=3 \text {, Very high }=4\end{array}$ \\
\hline
\end{tabular}

\section{(c) $\mathbf{E Y}$}

This work is licensed under a Creative Commons Attribution 3.0 License. 